\section{Teknologihistorie av beste merke}

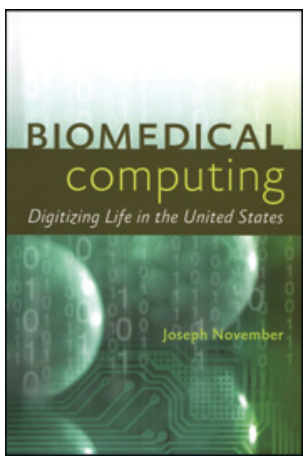

\section{Joseph November}

\section{Biomedical computing}

Digitizing life in the United States. 344 s, ill. Baltimore, MD: The Johns Hopkins University Press, 2012. Pris USD 60 ISBN 978-1-4214-0468-4
«Lighting a match on gasoline delivery day, with our exchange system frequenctly belching finely charred particulate matter, challenged even the most intrepid souls». Slik introduseres en av bokens tallrike anekdoter, her fra National Institute of Health i Bethesda, Maryland, hvor datamaskinene og deres brukere var henvist til de kummerligste lokaler under dyrestallen, hvor ventilasjonen tok inn dyremøkk og bensindamp fra instituttets drivstofflager.

Dette er historien om informasjonsteknologiens trange fødsel i biomedisinsk forskning på 1950- og 60-tallet. Historien tar utgangspunkt i USA, hvor de første gjennombruddene skjedde i denne perioden.

Historikeren Joseph November beskriver på en fengslende måte hvordan den nye teknologien går fra trange kår til å nærme seg posisjonen den har i dag. Han tilbyr samtidig en skattkiste av velskrevne, spennende og morsomme historier. Det er lenge siden jeg har ledd høyt av en bok om IT. Forfatteren går imidlertid lenger enn å underholde, han viser hvordan teknologien utfordret forskernes syn på egen virksomhet og egne arbeidsmetoder. Det er tankevekkende å lese betraktninger av forskere fra en annen æra, hvor kvantitative metoder og statistisk signifikans slett ikke var så rotfestet som i dag. I denne virkeligheten fremsto de enorme, kostbare datamaskinene som fremmedelementer, og få forskere var overbevist om at det var bryet verdt å punche papirstrimler og stå i kø for å bruke datamaskinene.

Han beskriver en grunnleggende konflikt som kom til å prege perioden: Må biomedisinsk forskning tilpasse seg informasjonsteknologi, eller omvendt? På den ene siden ble store pengebeløp tildelt forskningsmiljøene av institusjoner som ønsket å oppdra motstridende forskerne til å forenkle sine problemstillinger og teorier til matematiske formler datamaskinene kunne håndtere. På den andre siden kom det første virkelige gjennombruddet i IT-støttet biomedisinsk forskning med LINC, en datamaskin som ga brukerne direkte kontroll fremfor å måtte sende programmet fra seg og få svar noen dager senere. Selv om datamaskinenes kapasitet knapt er en utfordring lenger, er de underliggende verdimotsetningene også interessante i dag. Likeså er datidens entusiastiske forsøk på å skape kunstig intelligens innen medisinen interessant, og på mange måter noe vi kan smile av nå. Entusiasmen på teknologiens vegne kan vi like fullt kjenne igjen i egne rekker. (Tør jeg nevne Big Data?)

Jeg hadde stor glede av denne boken, og jeg vil varmt anbefale den til alle forskere og enhver med interesse for teknologiens innflytelse på medisinfaget.

\section{Hallvard Lærum}

Stab IKT

Oslo universitetssykehus

\section{Hvorfor lese skjønnlitteratur?}

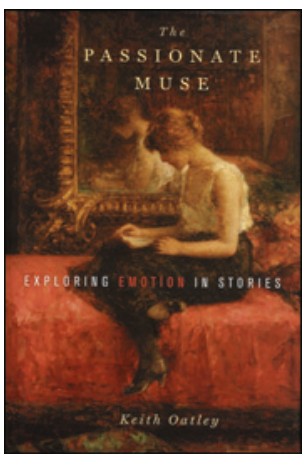

\section{Keith Oatley \\ The passionate muse}

Explorations of emotions in stories. $216 \mathrm{~s}$, ill. Oxford: Oxford University Press, 2012. Pris GBP 19

ISBN 978-0-19-976763-2

Har en bok om følelsene i skjønnlitteraturen noen interesse for leger? Forfatterens svar vil utvilsomt være: JA. Og begrunnelsen ville være at siden vi klinikere hele tiden befinner oss i en situasjon fylt av pasienters og egne følelser, både negative og positive, er det særlig viktig at vi både kan identifisere egne og andre menneskers følelser, og håndtere dem slik at de ikke kommer i veien for diagnostikk, behandling, omsorg og etterlevelse.

Hvordan blir vi god til det? Én måte kan være å lese mye skjønnlitteratur, sier forfatteren. Lesing av skjønnlitteratur kan vekke både gode og vanskelige følelser, men fordi vi har en viss distanse til karakterene, kan disse følelsene tolereres og bli et utgangspunkt for å kjenne oss igjen hos andre, og for refleksjon over egen person og egne relasjoner. De kan også vekke viktige emosjonelle minner som ligger der og påvirker oss på et ubevisst plan så lenge vi ikke blir klar over dem. Jo mer vi forstår av hva som motiverer andre mennesker (og oss selv) til å tenke, føle og handle slik de gjør (mentalisering), desto bedre vil vi kunne få kontakt og samarbeide med andre, og desto bedre vil vi kunne vise empati.

Forfatteren er amerikansk professor i psykologi, og han har særlig interessert seg for «the psychology of fiction». Her viser han både i et praktisk eksempel, som utgjøres av en lengre novelle, og $i$ teoretiske gjennomganger, hvilken kunnskap man nå har om virkningene av lesing av romaner og noveller (obs! sakprosa har ingen slik virkning) på leserens personlighet, velvære og forståelse av andre mennesker. Hans egen novelle er oppdelt i fem avsnitt, og etter hvert avsnitt diskuteres både hvordan teksten prøver å vekke leserens følelser og identifisering med hovedpersonene, og hva empirisk forskning har bidratt med av kunnskap, nettopp om slike fenomener.

Boken er lettlest, til dels spennende skrevet og vil være interessant for alle som liker å lese (eller selv skrive) skjønnlitteratur. Kanskje kan den også inspirere flere kolleger, som vil bli enda bedre leger, til å unne seg litt mer skjønnlitteratur.

Per Vaglum

Avdeling for medisinsk atferdsvitenskap

Universitetet i Oslo 